\title{
Eléments de réflexion sur le procès d'institution et de la transmission d'une culture corporelle : le cas de l'éducation physique scolaire
}

\section{Gilles Klein}

\section{OpenEdition}

\section{Journals}

Édition électronique

URL : http://journals.openedition.org/trema/2459

DOI : 10.4000/trema.2459

ISSN : 2107-0997

Éditeur

Faculté d'Éducation de l'université de Montpellier

Édition imprimée

Date de publication : 24 octobre 1997

Pagination : 33-46

ISSN : 1167-315X

Référence électronique

Gilles Klein, «Eléments de réflexion sur le procès d'institution et de la transmission d'une culture corporelle : le cas de l'éducation physique scolaire », Tréma [En ligne], Hors série $N^{\circ} 1$ | 1997, mis en ligne le 03 janvier 2011, consulté le 20 avril 2019. URL : http://journals.openedition.org/trema/2459 ; DOI : 10.4000/trema.2459

Ce document a été généré automatiquement le 20 avril 2019.

Trema 


\title{
Eléments de réflexion sur le procès d'institution et de la transmission d'une culture corporelle: le cas de l'éducation physique scolaire
}

\author{
Gilles Klein
}

\section{RÉSUMÉS}

L'étude des processus de rationalisation de l'éducation physique scolaire en France permet d'analyser la notion de culture corporelle. Elle permet de percevoir les spécificités du fonctionnement de l'institution et des relations des acteurs engagés dans l'action. Eviter le dissensus semble l'une des clefs pour comprendre les relations dans les commissions décisionnelles.

This study of the processes of rationalization in school PE in France enables us to analyse, the notion of body culture. The study also enables us to perceive the specificity of the way the institution works and of the relationships of the actors involved and their inter-actions with each other within the institution. Avoiding dissensus would seem to he the key to the understanding of the relationships within the decision-making committees. 
INDEX

Mots-clés : acteur, institution EPS, rationalisation

Keywords : actor, institution of PE, rationalization

\section{AUTEUR}

\section{GILLES KLEIN}

Laboratoire acquisition et transmission des habilités motrices EA-2044, université Paul Sabatier de Toulouse 